

Edukatif : Jurnal Ilmu Pendidikan Volume 3 Nomor 2 Tahun 2021 Halm 578 - 588

EDUKATIF: JURNAL ILMU PENDIDIKAN

Research \& Learning in Education

https:/ledukatif.org/index.php/edukatif/index

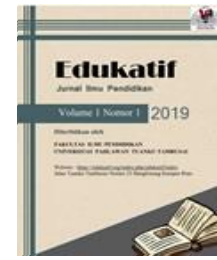

\title{
Program Bimbingan Dan Konseling Untuk Mengembangkan Kecerdasan Spiritual Dan Emosional Siswa
}

\author{
Nanik Suryati $^{1 \bowtie}$, Mohammad Salehudin ${ }^{2}$ \\ Institut Agama Islam Negeri Samarinda, Indonesia ${ }^{1,2}$ \\ E-mail : naniksuryati81@ gmail.com ${ }^{1}, \underline{\text { salehudin @iain-samarinda.ac.id }}^{2}$
}

\begin{abstract}
Abstrak
Kecerdasan spiritual dan emosional siswa terkadang kurang tumbuh dengan baik dan dapat menghambat perkembangan berbagai aspek pada diri siswa itu sendiri. Tujuan Penelitian ini untuk mengetahui mengenai program bimbingan dan konseling untuk mengembangkan kecerdasan spiritual dan emosional siswa. Penelitian ini menggunakan pendekatan kualitatif dengan metode penelitian kepustakaan (library research) untuk menjawab pertanyaan penelitian. Berbagai perilaku menyimpang yang dilakukan siswa baik membolos, menyontek, bullying, tawuran dan lainnya dapat berpengaruh terhadap situasi belajarnya. Situasi belajar yang buruk dalam diri siswa dipengaruhi dari dari dalam dirinya sendiri dan lingkungan sekitarnya. Karena itu, kecerdasan spiritual dan kecerdasan emosional dalam dunia pendidikan sekolah perlu lebih ditingkatkan dan diperhatikan agar meminimalisir hal-hal yang tidak diinginkan baik yang telah maupun yang belum terjadi. Namun, hal tersebut masih bisa diperbaiki dan diwujudkan dalam program bimbingan dan konseling sebagai wadah untuk membangun kecerdasan siswa di sekolah terkhusus kecerdasan spiritual dan kecerdasan emosional. Kedua kecerdasan tersebut mempunyai peranan yang sangat penting terhadap karakter, normanorma, nilai dan perilaku siswa di sekolah.
\end{abstract}

Kata Kunci: Program Bimbingan dan Konseling, Kecerdasan Spiritual, Kecerdasan Emosional, Siswa.

\begin{abstract}
Students' spiritual and emotional intelligence sometimes do not grow well and can hinder various aspects in their self-development. The purpose of this study is to find out the extent of counseling programs in developing students' spiritual and emotional intelligence. This study uses a qualitative approach with library research methods to answer research questions. Students' aberrant behaviors, including truancy, cheating, bullying, fighting and others can affect their learning performance. Students' bad learning performance is a product of internal factors and the surrounding environment. Therefore, spiritual intelligence and emotional intelligence in the world of education need to be further improved and considered in order to minimize undesirable things that happen or might happen. However, it can still be improved and manifested through school counseling programs as a forum to build students' intelligence in schools, especially spiritual intelligence and emotional intelligence. Both intelligences have a very important role in their character, norms, values and behavior of students in school.
\end{abstract}

Keywords: Counseling Program, Spiritual Intelligence, Emotional Intelligence, Students.

Copyright (c) 2021 Nanik Suryati, Mohammad Salehudin

$\triangle$ Corresponding author

Email : naniksuryati81@gmail.com

DOI : https://doi.org/10.31004/edukatif.v3i2.349

ISSN 2656-8063 (Media Cetak)

ISSN 2656-8071 (Media Online)

Edukatif : Jurnal Ilmu Pendidikan Vol 3 No 2 Tahun 2021 p-ISSN 2656-8063 e-ISSN 2656-8071 


\section{PENDAHULUAN}

Pendidikan memiliki peranan yang sangat penting dalam kemajuan bangsa. Oleh karena itu, setiap lembaga institusi memenuhi kebutuhan anak didiknya, bangsa, maupun masyarakat dalam proses pendidikan yang dijalankan. Pendidikan dilakukan tidak hanya guna meningkatkan potensi yang dimiliki anak didik saja. Melainkan menjadikan anak didik agar mempunyai kepribadian yang baik, kekuatan spiritual keagamaan, kecerdasan, pengendalian diri, dan berahklak mulia dan keterampilan yang dibutuhkan oleh dirinya, masyarakat, bangsa maupun negara (Marisa, 2015). Namun, kemerosotan moral dapat terjadi dalam dunia pendidikan seperti, individu kesulitan dalam mengontrol emosi atau mempunyai perilaku agresif seperti, menyalahkan, berkelahi, mengolok-olok dan lainnya (Tutiani, 2017).

Dalam penelitian Alifia Fermanda Putri menyatakan bahwa lingkungan dapat mempengaruhi pembentukan dan pertumbuhan karakter serta tingkah laku yang terlihat ketika individu bersosialisasi kepada lingkungan masyarakat dan tempat sekolahnya. Terkait fenomena yang telah terjadi tidak sedikit siswa yang berperilaku agresif terhadap teman maupun gurunya di sekolah. Tindakan agresif yang dilakukan berupa tindakan verbal maupun fisik. Hal tersebut yang membuat suatu perilaku yang telah terlihat tergantung dari kondisi lingkungan individu (Putri, 2019). Hasil Penelitian tersebut menunjukkan bahwa perilaku agresif sangat berpengaruh terhadap siswa. Sehingga, sekolah dalam bidang pendidikan memerlukan kecerdasan spiritual (Spiritual Quotient/SQ) dan kecerdasan emosional (Emotional Quotient/EQ) (Agustian, 2001) untuk membantu perkembangan dan meningkatkan kualitas diri para siswanya.

Kecerdasan Spiritual berfungsi untuk mengintergasikan kecerdasan emosional dan kecerdasan Intelektual dimana merupakan suatu potensi yang ada dalam diri manusia. Sehingga, individu memiliki suatu nilai moralitas yang tinggi. Kemudian disisi lain, kecerdasan emosional ini membantu untuk memahamkan individu terkait apa yang dirasakan orang lain dan dapat mendorong individu untuk menuju ke arah perilaku yang lebih positif. Selain itu, kecerdasan emosional berpengaruh terhadap karakter pribadi individu. Dimana saat siswa hanya mengandalkan kecerdasan intelektualnya (Intelligence Quotient/IQ) saja maka ia akan memiliki sifat mudah besar kepala, sombong, dan susah dinasihati. Kemudian, jika siswa hanya mengunggulkan kecerdasan spiritualnya saja maka dapat memungkinkan ia akan kesulitan untuk mengendalikan diri saat mulai mengetahui kekurangan yang ada dalam dirinya. Jika kecerdasan emosional yang hanya di kuasai individu akan sukar untuk memahami terkait makna hidupnya tersebut (Fajar Dita Sari, 2019). Adanya kecerdasan spiritual dan kecerdasan emosional pada diri siswa maka mereka akan mempunyai pengendalian diri yang seimbang sehingga membawa pengaruh yang positif terhadap motivasi belajar, dirinya sendiri, dan lingkungan sekitarnya. Sehingga siswa juga dapat menjalin hubungan yang harmonis kepada teman-teman dan lingkungannya sekolah. Dimana saat siswa mampu mengasah kecerdasan emosional ia mampu untuk mengenal dirinya sendiri dan emosi orang lain, dapat mengatur suasana hatinya, memotivasi diri sendiri, sehingga dapat mengelola dengan baik emosi yang ada dalam dirinya sendiri dalam berhubungan dengan orang lain. Sedangkan kecerdasan spiritual siswa dapat menyelesaikan permasalahannya dengan berlandaskan nilai-nilai spiritual atau dari keagamaan yang diyakini oleh individu. Karena, kecerdasan spiritual berhubungan dengan hati nurani yang membuat indiviidu menjadi lebih kreatif, mempunyai wawasan yang luas, optimis, berani, dan lainnya.

Hal lain yang turut diperhatikan terkait prestasi belajar siswa. Dimana, jika seorang siswa belum mempunyai kecerdasan emosional yang baik ia akan kurang mampu dalam menyelesaikan konfliknya. Lalu, menimbulkan permasalahan yang berkaitan dengan prestasi belajarnya di sekolah. Selain itu, kecerdasan spiritual juga menjadi hal penting dalam meningkatkan prestasi belajar siswa. Siswa yang memiliki kecerdasan intelektual dan kecerdasan emosional namun kecerdasan spiritualnya belum terpenuhi maka dalam menuju kesuksesannya tersebut belum maksimum. Karena, kecerdasan intelektual untuk kemampuan berpikir 
memahami materi, kecerdasan emosional berguna dalam mengendalikan emosi, dan kecerdasan spiritual sebagai penyeimbang kecerdasan emosi yang berguna untuk jangka panjang. Sehingga tiga kecerdasan tersebut saling berkaitan dalam mewujudkan prestasi belajar siswa (Sulastyaningrum et al., 2019).

Dalam mengembangkan kecerdasan spiritual dan kecerdasan emosional siswa di sekolah perlunya proses dalam periode waktu tertentu. Karena, berbagai kemerosotan moral dapat terjadi kapan saja dan setiap siswanya memiliki karakter serta permasalahan yang berbeda - beda. Perlunya pelayanan dan juga kegiatan positif untuk mengembangkan kecerdasan spiritual dan kecerdasan emosional siswa. Pelayanan dan kegiatan positif tersebut dapat ditunjang melalui program bimbingan dan konseling di sekolah. Kecerdasan spiritual dan kecerdasan emosional siswa menurun dapat ditandai dengan adanya perilaku menyimpang yang terjadi di lingkungan sekolah baik, bullying, kekerasan dalam pertemanan yang menyebabkan bahkan memungkinkan terjadinya pembunuhan seperti kasus - kasus yang beredar (Amaliah et al., 2020). Namun, tidak semua siswa mempunyai suatu kesadaran dalam dirinya untuk menghindari atau menjauhi perilaku-perilaku menyimpang tersebut. Terdapat siswa yang pintar atau pandai dalam belajar, namun kurang mempunyai kesadaran untuk menjauhi perilaku yang menyimpang tersebut (Fajar Dita Sari, 2019). Tentunya hal tersebut menimbulkan dampak negatif bagi dirinya sendiri dan lingkungan sekitarnya. Hal tersebut menjadi perhatian yang khusus untuk sekolah dalam meningkatkan kualitas pendidikannya. Oleh karena itu, kecerdasan spiritual dan kecerdasan emosional memiliki peranan yang sangat penting dalam membentuk karakter siswa di sekolah agar dapat meminimalisir atau kemerosotan moral yang belum dan sudah terjadi (Amaliah et al., 2020).

Howard Gardner (Fuad, 2012) menyatakan bahwa kecerdasan merupakan suatu kemampuan guna menyeselaikan segala permasalahan atau persoalan dalam kehidupan dan dapat menghasilkan produk atau jasa yang berguna dalam mencangkup berbagai aspek kehidupan. Menurutnya, terdapat sembilan macam atau aspek kecerdasan yang dimiliki manusia yang berpotensi untuk dikembangkan tiap anak yang lahir tanpa disertai oleh cacat fisik diotaknya. Sembilan aspek tersebut yaitu, kecerdasan gambar atau spasial, kecerdasan interpersonal, kecerdasan kinestetik atau fisik, kecerdasan verbal atau bahasa, kecerdasan intrapersonal atau mengenal diri sendiri,kecerdasan musik, kecerdasan mempelajari alam, kecerdasan logika atau matematika, dan kecerdasan spiritual. Merujuk pada permasalahan yang dibahas yakni menurunnya moralitas sehingga berpengaruh pada kecerdasan spiritual dan juga kecerdasan emosional siswa di sekolah. Menurut Wahab dan Umiarso (Fitra Hamdika, 2018) berpendapat bahwa, kecerdasan spiritual merupakan kecerdasan yang mana telah ada dalam setiap manusia dimulai dari individu lahir dimana hal tersebut membuat manusia akan menjalani hidup dengan penuh kebermaknaan, individu akan selalu mendengarkan suara hati nuraninya, tidak pernah merasa suatu hal yang sia-sia, semua yang individu jalani akan selalu bernilai. Sedangkan kecerdasan emosional menurut Ginanjar (Metasari, 2019) yaitu, diartikan sebagai suatu kemampuan untuk mendengarkan bisikan emosional, dan menjadikannya sebagai suatu sumber informasi yang penting guna memahami diri sendiri dan orang lain demi mencapai suatu tujuan.

Layanan bimbingan dan konseling mempunyai andil yang cukup berpengaruh dalam mengembangkan kualitas pendidikan di sekolah. Seperti yang dijelaskan sebelumnya bahwa lembaga pendidikan harus memenuhi kebutuhan peserta didik. Pemenuhan itu salah satunya dapat dilakukan melalui program bimbingan dan konseling di sekolah. Bimbingan dan konseling sebagai wadah guna membantu untuk mengembangkan kehidupan siswa baik dari belajar, sosial, pribadi, maupun perencanaan karir. Maka, dengan hal ini adanya bimbingan dan konseling di sekolah bukanlah hanya karena ada ataupun tidak adanya suatu ketentuan yang diberikan atau telah ditetapkan. Namun, yang menjadi hal penting ialah berkenaan dengan memberikan fasilitas siswa sebagai konseli di sekolah untuk mengembangkan potensi yang ada dalam dirinya atau guna mencapai tugas perkembangan siswa baik dari segi aspek fisik, intelektual, sosial, emosi, dan moral atau spiritual (Marisa, 2015).Maka, bimbingan dan konseling ialah suatu layanan yang diberikan oleh ahlinya disebut konselor atau guru bimbingan dan konseling yang bertugas sebagai tenaga kependidikan dengan 
memiliki kekhususan pada bidang bimbingan dan konseling yang ikut serta dalam menyelenggarakan pendidikan. Konselor akan memberikan berbagai layanan bimbingan dan konseling sesuai dengan kebutuhan siswanya (Kamaluddin, 2011). Sehingga konselor juga dapat membantu sekolah dalam meningkatkan kecerdasan spiritual dan emosional siswa disekolah. Saat siswa memiliki kecerdasan spiritual dan kecerdasan emosional yang seimbang maka ia dapat menyelaraskan kehidupannya agar menjadi lebih baik. Terdapat faktor yang mempengaruhi kecerdasan spiritual dan emosional yakni dari faktor internal dan eksternal. Faktor internal berasal dari dalam diri individu sendiri yakni menyangkut aspek fisiologis yang dapat mempengaruhi kepribadian individu dimana misalnya memiliki cacat fisik sehingga merasa minder dan aspek psikologis atau yang dikenal dengan faktor kerohanian. Sedangkan dari faktor eksternal sendiri berasal dari faktor lingkungan yang meliputi masyarakat, keluarga, dan sekolah (Nur Hanifah, 2018).

Penelitian ini untuk meningkatkan wawasan terkait pentingnya kecerdasan spiritual dan kecerdasan emosional siswa disekolah. Hal ini terlihat dari fenomena yang marak terjadi di sekolah dengan banyaknya kenakalan remaja, putus sekolah, dan berbagai perilaku menyimpang lainnya yang dilakukan oleh siswa. Dimana berbagai fenomena tersebut telah terjabarkan dalam penelitian sebelumnya. Namun, permasalahan yang terjadi bukan hanya itu saja melainkan berkenaan dengan kurangnya rasa percaya diri, tidak mudah bergaul, dan kurangnya pemahaman terkait kecerdasan spiritual dan emosional siswa. Sehingga, hal tersebut menjadi perhatian yang penting terkhusus untuk peran guru bimbingan dan konseling sendiri di sekolah. Maka, dalam menangani berbagai permasalahan yang terjadi dikalangan siswa tersebut yaitu dengan cara meningkatkan kecerdasan spiritual dan kecerdasan emosional melalui program bimbingan dan konseling di sekolah. Harapannya dengan adanya penelitian ini dapat meningkatkan kecerdasan spiritual dan emosional siswa melalui program bimbingan dan konseling yang ada di sekolah agar siswa menjadi pribadi yang lebih baik. Sehingga dalam aplikasinya bukan hanya di lingkungan sekolah juga melainkan membawa pengaruh positif bagi dirinya dan masyarakat sekitar. Terkait beberapa penjabaran di atas, tujuan dari penelitian ini untuk mengetahui mengenai program bimbingan dan konseling untuk mengembangkan kecerdasan spiritual dan emosional siswa. Maka, dari tujuan tersebut terdapat suatu pertanyaan mengenai masalah penelitian yakni: Bagaimana program bimbingan dan konseling dalam meningkatkan kecerdasan spiritual dan kecerdasan emosional siswa? Maka, berdasarkan latar belakang yang dijabarkan peneliti tertarik untuk membuat suatu penelitian yang berjudul "Program Bimbingan dan Konseling Untuk Mengembangkan Kecerdasan Spiritual dan Emosional Siswa”.

\section{METODE PENELITIAN}

Penelitian ini menggunakan pendekatan kualitatif dalam metode penelitian library research (Creswell, 1994; Sugiono, 2010) atau yang disebut dengan pendekatan kepustakaan. Bentuk kegiatan dalam studi kepustakaan ini dengan penggumpulan data, membaca, mencatat, dan mengolah bahan penelitian. Dimana pengumpulan data tersebut diperoleh dari berbagai sumber bacaan yang didapatkan dari google books, google scholar, dan website lainnya seperti buku, jurnal, dokumen yang berbentuk elektronik dan cetak, dan berbagai sumber data atau informasi lain yang relevan dengan penelitian.(Supriyadi, 2016). Terdapat langkah-langkah dalam melakukan penelitian kepustakaan yakni: (a) mempunyai ide yang berkenaan dengan topik penelitian, (b) mencari informasi sebagai pendukung, (c) lebih mempertegas fokus penelitian dan mengorganisasikan bahan-bahan bacaan, (d) mencari bahan bacaan seperti artikel jurnal, buku, dokumen dan sumber bacaan yang lainnya baik offline maupun online, (e) menyusun dan mencatat bahan penelitian, (f) meringkas dan memperluas bahan bacaan yang diperoleh, (g) menyusun kembali bahan atau catatan yang diperoleh dan memulai untuk menulis.(Zed, 2014) 
DOI: https://doi.org/10.31004/edukatif.v3i2.349

\section{HASIL DAN PEMBAHASAN}

\section{Program dan Layanan BK di Sekolah}

Bimbingan dan konseling adalah suatu wadah yang diberikan kepada para siswa untuk membantu mereka dalam mengaplikasikan atas ilmu pengetahuan yang telah didapatkan dari hasil proses belajar, sehingga dapat bermaanfat di kehidupan sehari-harinya. Bimbingan dan konseling memiliki program dan layanan di sekolah (Rasimin et al., 2021). Menurut (Sumitri, 2017), program bimbingan dan konseling merupakan suatu rencana yang dilaksanakan pada periode tertentu dimana telah dirancang oleh konselor sekolah atau guru bimbingan dan konseling bersama warga sekolah. Adapun menurut Pusat Pengembangan dan Pemberdayaan Pendidik dan Tenaga Kependidikan Penjas dan BK pada tahun 2009 menerangkan bahwa, terdapat lima jenis program bimbingan dan konseling tersebut, yakni: Pertama, program tahunan meliputi semua kegiatan pendukung dan pelayanan dalam satu tahun untuk masing-masing kelas. Kedua, program semesteran yakni penjabaran dari program tahunan dimana masing-masing kelas mendapatkan kegiatan pelayanan dan pendukung dalam satu semester. Ketiga, program bulanan yakni penjabaran dari program semesteran yang dalam satu bulan meliputi kegiatan pelayanan dan kegiatan pendukung. Ketiga, program mingguan yakni penjabaran dari program bulanan yang dalam satu minggu meliputi kegiatan pelayanan dan kegiatan pendukung. Keempat, program harian yakni penjabaran dari program mingguan dalam bentuk rencana program pendukung atau RPP. Dalam satu minggu program pelayanan bimbingan dan konseling ini hanya dilakukan pada hari tertentu saja.(Sumitri, 2017)

Maka, dalam hal ini program layanan bimbingan dan konseling yang di buat oleh konselor sekolah atau guru BK tersebut akan dirancang secara sistematis dengan mengikuti ketentuan beberapa jenis program layanan tersebut. Pelayanan bimbingan dan konseling di sekolah ialah suatu upaya untuk membantu siswa guna mengembangkan kehidupan pribadi, sosial, perencanaan karir, dan kegiatan belajarnya. Lancarnya suatu program bimbingan dan konseling ini tentunya memerlukan dukungan dari berbagai pihak tidak hanya dari guru BK atau konselor sekolah saja melainkan guru-guru lainnya juga yang secara langsung berinteraksi dengan siswa, Dimana, jika diminta andil terkait terselenggaranya program tersebut, guru-guru yang lain memiliki beberapa peran seperti sebagai informator, fasilitator, mediator, dan kolaborator.

Adapun layanan Bimbingan dan Konseling untuk membantu mengatasi permasalahan siswa. Pertama, layanan orientasi yakni bentuk layanan untuk siswa dalam mengenal lingkungan barunya. Kedua, penempatan dan penyaluran ialah layanan guna membantu siswa mendapatkan penempatan dan penyaluran yang sesuai seperti dalam hal kelompok belajar, kelas, ekstrakulikurer dan lainnya. Ketiga, penguasaan konten yakni membantu siswa dalam menguasai konten tertentu baik dari kompetensi ataupun suatu kebiasaan yang dapat berguna untuk lingkungannya. Keempat, bimbingan dan konseling perorangan yakni bentuk layanan guna membantu siswa mengentaskan permasalahan pribadinya. Kelima, bimbingan kelompok layanan berbentuk dinamika kelompok untuk mengembangkan peribadi, karir, sosial, dan keputusan. Keenam, bimbingan dan konseling kelompok yakni suatu diskusi kelompok dalam membahas dan memecahkan permasalahan individu. Ketujuh, konsultasi yakni memberikan suatu bantuan kepada siswa melalui pihak lain guna mendapatkan wawasan atau cara yang dilakukan guna menangani masalah siswa. Kedelapan, mediasi yaitu membenahi persoalan hubungan antar mereka (Hikmawati, 2016).

\section{Hubungan Kecerdasan Spiritual, Kecerdasan Emosional dan Siswa}

Seperti yang dijelaskan sebelumnya pada bagian pendahuluan bahwa terdapat banyak jenis kecerdasan. Dimana manusia memiliki banyak kecerdasan yang ada didalam dirinya. Namun, hanya beberapa yang dominan diantara kecerdasan tersebut. Meskipun setiap individu mempunyai kecerdasan yang lahiriah 
dominannya hanya beberapa saja, namun kecerdasan spiritual dan kecerdasan emosional sangatlah penting terlebih untuk siswa. Dua kecerdasan ini dapat berpengaruh terhadap situasi belajarnya. Dimana dalam hasil penelitian (Unnisa, 2019)menyatakan bahwa keberhasilan belajar yang diperoleh siswa bukan hanya dari pengaruh kecerdasan intelektual saja. Karena, kecerdasan intelektual akan lebih efektif jika ditambah secara bersamaan dengan adanya kecerdasan spiritual dan kecerdasan emosional. Kemudian, dalam penelitiannya ia juga menerangkan bahwa jika siswa-siswa memiliki kecerdasan spiritual dan kecerdasan emosional maka mereka akan bisa untuk dapat mengerti terkait permasalahan dalam proses belajar mengajarnya disekolah. Selain itu, siswa-siswi akan dapat memberikan dorongan motivasi terhadap dirinya sendiri untuk semangat belajar dan dapat lebih menghargai hubungannya dengan orang lain di lingkungan sekolah. Hal ini sejalan dengan penelitian (Rampisela et al., 2017) menyatakan bahwa masih banyak orang yang mempunyai pandangan jika penentu kesuksesan seseorang itu dari kecerdasan Intelligence Quotient yang pada kenyataannya terdapat kecerdasan lain untuk penentu kesuksesan yakni Spiritual Quotient dan Emotional Quotient. Selain itu, dalam hasil penelitiannya terdapat suatu hubungan antara kecerdasan spiritual dan kecerdasan emosional terhadap prestasi belajar siswa (Rampisela et al., 2017), maka, kecerdasan spiritual dan kecerdasan emosional mempunyai pengaruh yang sangat besar terhadap proses belajar mengajar siswa di sekolah. Saat sisi emosional dan spiritual siswa lebih baik maka akan berpengaruh positif terhadap situasi belajarnya yang menyangkut dengan kecerdasan intelektual tersebut.

Selain berpengaruh terhadap proses belajar siswa, terdapat permasalahan lain yang menjadikan kecerdasan spiritual dan emosional itu penting yaitu berkaitan dengan moralitas dan norma-norma yang terjadi di lingkungan sekolah. Berdasarkan hasil penelitian (Restu \& Yusri, 2013) menyatakan bahwa, terdapat perilaku agresif di sekolah seperti agresif fisik, benda, dan verbal yang disebabkan oleh frustasi,provokasi, kepatuhan atau kekuasaan dan suhu udara. Selain itu, untuk mengatasi permasalahan tersebut dalam penelitiannya menerangkan bahwa memberikan layanan BK pada siswa seperti layanan informasi, penguasaan konten, konseling kelompok dan individual. Sedangkan, hasil penelitian (Merdekasari \& Chaer, 2017) menyatakan bahwa terdapat perbedaan antara siswa laki-laki dan perempuan terhadap tingkatan perilaku agresi ini. Perbedaan tersebut dapat dilihat dari perilaku agresi verbal dan fisik antara siwa laki-laki dan perempuan. Sedangkan persamaannya dalam aspek kebencian dan amarah antara siswa laki-laki dan perempuan. Hal yang sama dengan pendapat Carlo (Merdekasari \& Chaer, 2017) bahwa ada faktor yang menyebabkan perilaku agresi antara siswa laki-laki dan perempuan yakni dari segi kepribadian dan sosial. Dimana, perempuan memiliki kepribadian yang lebih simpatik dibandingkan laki-laki sehingga membuatnya kurang untuk menunjukkan sikap agresi (Merdekasari \& Chaer, 2017). Siswa sebagai remaja, jika memiliki emosi yang kuat daripada daya pikirnya maka hal tersebut dapat mempunyai pengaruh terhadap kecerdasan emosionalnya. Maka, saat individu tidak cerdas dalam mengendalikan emosinya akan memicu timbulnya kenakalan remaja atau perilaku menyimpang.(Kairupan et al., 2019) Perilaku menyimpang yang sering dijumpai seperti bolos sekolah, tawuran antar sekolah, tindakan yang kriminal, dan berpacaran.(Fithriyana, 2019)

Menurut Zohar (Daudiah \& Rahayu, 2013) menyatakan bahwa, hubungan kecerdasan spiritual dan kenakalan remaja terletak dimana dalam kecerdasan spiritual terlihat adanya berbagai sifat yang baik serta hati nurani dan juga potensi yang luar biasa didalam diri manusia sehingga dapat berguna untuk mengembangkan pribadi individu kepada karakter yang lebih baik. Dimana kecerdasan spiritual ini nantinya akan menyadarkan para siswa sebagai remaja untuk sadar jika mereka mempunyai masalah eksistensial dan juga membuat mereka bisa mengatasi ataupun berdamai dengan permasalahan yang dimiliki agar kehidupannya bermakna dan lebih baik (Daudiah \& Rahayu, 2013), ketika kecerdasan spiritual tersebut digunakan terus menerus maka hasilnya ialah individu tidak akan melakukan perbuatan-perbuatan yang negatif lagi baik menyimpang maupun kenakalan remaja (Karimah, 2017), bahwa kecerdasan spiritual dan kecerdasan emosional sangat 
584 Program Bimbingan Dan Konseling Untuk Mengembangkan Kecerdasan Spiritual Dan Emosional Siswa - Nanik Suryati, Mohammad Salehudin

DOI: https://doi.org/10.31004/edukatif.v3i2.349

berpengaruh terkhusus untuk siswa di sekolah. Bentuk-bentuk perilaku negatif yang dilakukan dapat mempengaruhi proses belajar mengajar siswa di sekolah. Oleh karena itu, sekolah juga perlu mendukung perkembangan kecerderdasan - kecerdasan siswa baik dari aspek spiritualitas dan emosional seperti memberikan dan mendukung program bimbingan dan konseling di sekolah.

\section{Bentuk-Bentuk Layanan Bimbingan Dan Konseling Dalam Meningkatkan Kecerdasan Spiritual Dan Kecerdasan Emosional Siswa Di Sekolah}

Dalam meningkatkan kecerdasan spiritual dan kecerdasan emosional siswa tentunya sekolah memerlukan suatu proses dan juga pendukung sebagai penunjang yang dijadikan sarana membentuk kecerdasan tersebut Beberapa hasil penelitian sebelumnya telah menerangkan bahwa untuk meningkatkan kecerdasan spiritual dan kecerdasan emosional disekolah yakni dengan melalui program bimbingan dan konseling. Dimana didalam program bimbingan dan konseling tersebut terdapat berbagai layanan yang dapat di jadikan sarana ataupun wadah membangun dan meningkatkan kecerdasan spiritual dan kecerdasan emosional siswa. Sarana dalam membentuk kecerdasan tersebut dapat dilakukan dengan memberikan bimbingan kelompok. Berdasarkan hasil penelitian (Ulandari \& Juliawati, 2019) menyatakan bahwa bimbingan kelompok memberikan pengaruh yang signifikan terhadap perkembangan kecerdasan emosi siswa. Dimana, dalam pelaksanaan bimbingan kelompok siswa akan memperoleh segala informasi dari kawan atau anggota lainnya dan belajar bersama untuk berbagi pengalaman serta bertukar pikiran. Selain itu, guru BK mempunyai peran yang cukup besar dalam mengembangkan kecerdasan emosional dengan memberikan pengetahuan kepada siswanya terkait cara untuk mengelola emosi, mengenal diri sendiri, memotivasi diri, cara untuk mengenal emosi orang lain dan berhubungan dengan orang lain. Sehingga, dengan memberikan hal-hal tersebut siswa dirahapkan mampu untuk berpikir terbuka dan aktif dengan seperti ini juga dapat melatih rasa percaya diri siswa untuk berbicara didepan umum.

Berbeda dengan penelitian (Melianasari, 2016) menyatakan bahwa, terdapat hasil yang efektif dalam meningkatkan kecerdasan emosi siswa dengan menggunakan bimbingan kelompok melalui teknik permainan simulasi. Diperkuat oleh hasil penelitian (Lestari, 2012) menujukan bahwa permainan simulasi ini akan melibatkan siswa untuk turut aktif terhadap dinamika kelompok dengan suasana yang menyenangkan, dimana siswa akan memainkan peran yang situasinya menyerupai kehidupan nyata. Permainan tersebut diberikan dengan suasana yang menyenangkan direfleksikan dengan realitas di kehidupan sehari-hari. Hal tersebut akan menarik untuk siswa sehingga mereka akan senang dan terlibat secara lebih mendalam dalam bimbingan kelompok yang dilaksanakan. Selain itu, siswa akan menguasai keterampilan intelektual, sosial, konsep dan motorik dalam bidang yang dipelajari serta bisa untuk belajar melewati keadaan tiruan dengan sistem umpan balik dan juga penyempurnaan yang berkelanjutan. Maka, bimbingan kelompok dengan memadukan permainan simulasi dapat lebih seru dan membuat peserta tidak merasa kebosanan.

Selain bimbingan kelompok yang dapat meningkatkan kecerdasan spiritual dan kecerdasan emosional siswa, terdapat konseling individual untuk membentuk kecerdasan spiritual siswa. Karena, siswa juga mempunyai berbagai permasalahan baik dari keluarga, teman sebaya, gangguan belajar, dan lainnya. Konseling individual ini digunakan untuk membuka peluang siswa dalam mengungkapkan perasaan dan permasalahan yang dialami agar lebih luas dengan konselor secara dua arah saja. Banyak dijumpai siswa kurang semangat dalam belajar, murung, menyendiri, mengalami permasalahan belajar, susah dalam memahami pelajaran, atau ada perilaku-perilaku yang kurang sesuai dengan norma yang berlaku. Sehingga, konseling individual dapat menjadi acuan konselor dalam mencari informasi dan membantu siswa dalam membangun kearah yang lebih positif kembali. Hasil penelitian (Selviyana, 2020) menyatakan bahwa, terdapat tiga tahap untuk melakukan konseling individual diantaranya identifikasi masalah atau awal, tahap 
definisi masalah atau pertengahan, dan tahap akhir yakni keputusan untuk berbuat. Hasil yang didapat dari pembentukan kecerdasan spiritual dengan menggunakan konseling individual yaitu siswa bisa untuk menghidupkan kebenaran yang paling dalam, berbuat kebaikan, kesadaran dapat terbentuk dari dalam diri untuk berperilaku yang bernilai ibadah, dan dapat memecahkan persoalan hidupnya. Selain itu Selviyana menemukan hasil temuan dalam pelaksanaan konseling indiviudal di MA Sumber Bungur Sumber Bungur Pakong yakni siswa yang dapat mengelola kecerdasan spiritual yang baik yakni: bisa merasakan kehadiran Allah misalnya beribadah tiap waktu, bersyukur, dan berdoa sebelum pembelajaran dimulai. Kemudian mereka akan mempunyai kesadaran yang tinggi dan berpikir duluan sebelum melakukan hal yang menyimpang seperti memiliki kesadaran atas segala tindakan negatif yang tidak perlu untuk dilakukan baik memukul, menghina, bullying, dan tidak sopan kepada Tuhannya. Selanjutnya, mempunyai kemampuan untuk bersikap netral kepada dirinya sendiri dan juga orang lain seperti tidak membedakan kawan, bertanggung jawab, menyelesaikan tugas tepat waktu, saling membantu dan juga peduli terhadap dirinya sendiri maupun orang lain (Selviyana, 2020).

Seperti yang dijelaskan sebelumnya bahwa dalam pelaksanaan program bimbingan dan konseling perlunya dukungan dari semua pihak yang ada di sekolah. Terdapat beberapa program yang dapat digunakan untuk meningkatkan kecerdasan spiritual dan emosional siswa. Hasil penelitian (Jaelani, 2019) menyatakan bahwa untuk meningkatkan kecerdasan spiritual maupun kecerdasan emosional siswa guru bimbingan dan konseling sangat perlu untuk memberikan kebiasaan atau melatih siswa turut serta dalam berbagai aktifitas keagamaan, ibadah, kegiatan sosial, yang mencangkup ketiga program yakni kegiatan belajar dan mengajar, ubudiyah, dan sosial kemasyarakatan. Kegiatan belajar dan mengajar dengan dibekali pendidikan, praktik agama, dan baca doa sebelum belajar. Kegiatan ekstra yakni melaksanakan ibadah seperti sholat dhuha, membaca surah pendek dan bersedekah tiap hari jumat. Kemudian sosial kemasyarakatan seperti memberikan santunan kepada yang membutuhkan dan berkunjung ke panti-panti sosial (Jaelani, 2019), sedangkan hasil penelitian Imron Rosyadi (Muhammad et al., 2017) menyatakan bahwa upaya dalam meningkatkan kecerdasan emosional dan spiritual dapat dilakukan dengan melakukan berbagai aktivitas seperti mengikuti OSIS, Kepramukaan, kegiatan keagamaan, ekstrakulikurer keagamaan seperti tahfidz, dan poster kalimat yang positif. Meskipun, keduanya ada perbedaan dalam kegiatan yakni pemberian kegiatan sosial dan poster kalimat positif. Namun, kedua penelitian ini mendukung adanya kegiatan kerohanian dan kegiatan ekstra dalam mengembangkan minat dan bakat siswa.

Maka, dalam hal ini selain dibekali ilmu kereligiusan siswa mampu juga dalam meningkatkan soft skill yang dimiliki hal ini dapat menunjang dalam meningkatnya kepercayaan diri dan empati siswa. Kemudian dari berbagai program bimbingan dan konseling tersebut akan masuk dalam managemen pendidikan sekolah. Sehingga semua seluruh civitas akademika yang ada disekolah baik guru maupun siswa mendukung berbagai program tersebut. Sebagai contoh dalam kegiatan kerohanian, siswa beribadah atau berdoa sesuai kepercayannya masing-masing di ruangan yang berbeda seperti doa pagi bersama sebelum melaksanakan pembelajaran. Kemudian disusul ibadah siang dan sholat dzuhur berjamaah bagi yang beragama islam dilaksanakan sebelum pulang sekolah. Selain itu, dapat didukung dengan kegiatan kerohanian yang lainnya sebagai penunjang meningkatkan dua kecerdasan tersebut. Maka, guru juga ikut serta dalam ibadah atau berperan sebagai pembimbing. Selain itu, sebagai pelengkap program-program bimbingan konseling sebelumnya, guru BK juga perlu dalam memberikan pemahaman kepada siswa terkait pentingnya kecerdasan spiritual dan kecerdasan emosional siswa. Baik memberikan pemahaman terkait berbagai kecerdasan terkhusus kecerdasan spiritual dan emosional. Kemudian, pemahaman tindakan-tindakan yang positif dan negatif di kehidupan sehari-hari. Sehingga, siswa juga lebih paham dan juga sadar dalam mengolah tindakannya yang akan dilakukan dalam kehidupan sehari-harinya. 
DOI: https://doi.org/10.31004/edukatif.v3i2.349

\section{KESIMPULAN}

Hasil penelitian menemukan dari beberapa studi kepustakaan bahwa program bimbingan dan konseling mempunyai andil yang besar terhadap perkembangan kecerdasan spiritual dan kecerdasan emosional siswa. Dimana dalam program tersebut memberikan berbagai layananan bimbingan dan konseling sebagai penunjang siswa untuk mengoptimalkan kemampuan dan potensinya. Program bimbingan dan konseling tersebut mencangkup konseling individu, bimbingan dan konseling kelompok, dan layanan yang lainnya. Selain itu, dapat didukung dengan memeberikan pemahman seputar kecerdasan spiritual dan kecerdasan emosional dalam kehidupan sehari-hari. Berbagai program yang diberikan dapat kurang berjalan efektif apabila tidak ada guru bimbingan dan konseling serta dukungan dari semua pihak sekolah. Maka, semua civitas akademika yang ada di sekolah harus saling mendukung untuk meningkatkan kualitas diri siswa dan lembaga pendidikan itu sendiri. Kecerdasan spiritual dan kecerdasan emosional saling berkaitan dengan kecerdasan yang lain. Jika kecerdasan spiritual dan kecerdasan emosional baik dan lebih matang maka kecerdasan yang lain turut menjadi lebih baik. Sama halnya dengan perilaku perilaku yang menyimpang maka individu akan mempunyai penyesuaian diri yang baik dari sebelumnya. Berbagai perilaku menyimpang yang dilakukan siswa baik membolos, menyontek, bullying, tawuran dan lainnya dapat berpengaruh terhadap situasi belajarnya. Situasi belajar yang buruk dalam diri siswa dipengaruhi dari dari dalam dirinya sendiri dan lingkungan sekitarnya. Karena itu, kecerdasan spiritual dan kecerdasan emosional dalam dunia pendidikan sekolah perlu lebih ditingkatkan agar meminimalisir hal-hal yang tidak diinginkan baik yang telah maupun yang belum terjadi.

\section{DAFTAR PUSTAKA}

Agustian, A. G. (2001). Rahasia sukses membangun kecerdasan emosi dan spiritual, ESQ (Emotional Spiritual Quotient): Berdasarkan 6 rukun Iman dan 5 rukun Islam. Arga. https://books.google.co.id/books?id=g6V9AAAAMAAJ

Amaliah, A., Febrianti, T., \& Wibowo, D. E. (2020). Hubungan antara kecerdasan emosional dan kecerdasan spiritual dengan perilaku agresif remaja di smp negeri 278 jakarta. Guidance Jurnal Bimbingan Dan Konseling, 17(12), 20-28.

Creswell, J. W. (1994). Research Design: Qualitative and Quantitative Approaches. SAGE Publications, Inc.

Daudiah, I., \& Rahayu, F. D. (2013). Hubungan spiritual quotient (kecerdasan spiritual) dengan kenakalan remaja pada siswa smk negeri tutur kabupaten pasuruan. Jurnal Psikologi, 2(1), 31-38.

Fajar Dita Sari, F. (2019). Hubungan Tingkat Kecerdasan Apiritual (SQ) dan Kecerdasan Emosional (EQ) Terhadap Sikap Siswa Dalam Menghindari Perilaku Menyimpang Pada Siswa Kelas VIII MTSN 1 Kota Blitar. IAIN Tulungagung.

Fithriyana, R. (2019). Hubungan Fungsi Afektif Keluarga Dengan Pergaulan Bebas Remaja Di MTs Swasta Nurul Hasanah Tenggayun. EDUKATIF: Jurnal Ilmu Pendidikan, 2(23), 72-79.

Fitra Hamdika. (2018). Hubungan Antara Kecerdasan Spiritual dengan Kepribadian Siswa di SMA Nurul Iman Palembang. Universitas Islam Negeri Raden Fatah Palembang.

Fuad, M. (2012). Teori kecerdasan, pendidikan anak, dan komunikasi dalam keluarga. Jurnal Dakwah Dan Komunikasi, 6(1).

Hikmawati, F. (2016). Bimbingan dan Konseling. PT Raja Grafindo Persada.

Jaelani, A. Q. (2019). Strategi Peningkatan Kecerdasan Emosional dan Spiritual Siswa. Jurnal Dakwah Dan Komunikasi, 13(1), 97-106.

Kairupan, M., Karame, V., \& Karawisan, Y. V. (2019). Hubungan Kecerdasan Emosional dan Kecerdasan Spiritual Dengan Kenakalan Remaja di Kelas XI IPS SMA Negeri 1 Tombatu Kecamatan Tombatu. Jurnal Of Community and Emergency, 7(2), 255-269. 
587 Program Bimbingan Dan Konseling Untuk Mengembangkan Kecerdasan Spiritual Dan Emosional Siswa - Nanik Suryati, Mohammad Salehudin

DOI: https://doi.org/10.31004/edukatif.v3i2.349

Kamaluddin, H. (2011). Bimbingan dan Konseling Sekolah. Jurnal Pendidikan Dan Kebudayaan, 17(4), 447454.

Karimah, N. R. Al. (2017). Hubungan Antara Kecerdasan Spiritual Dengan Kenakalan Remaja Pada Siswa Kelas VIII SMP Al Muayyad Surakarta.

Lestari, I. (2012). Pengembangan Model Bimbingan Kelompok Dengan Teknik Simulasi Untuk Meningkatkan Kecerdasan Emosi Siswa. Jurnal Bimbingan Dan Konseling, 1(2), 89-94.

Marisa, C. (2015). Pengaruh Layanan Konseling dan Kecerdasan Ilmu Pengetahuan Sosial. Sosio-e-Kons, 7(3), 187-195.

Melianasari, D. (2016). Penerapan Layanan Bimbingan Kelompok Melalui Teknik Permainan Dan Untuk Meningkatkan Kecerdasan Emosi Siswa. Jurnal Ilmu Pendidikan, 14(2), 311-317.

Merdekasari, A., \& Chaer, M. T. (2017). Perbedaan perilaku agresi antara siswa laki-laki dan siswa perempuan di SMPN 1 Kasreman Ngawi. Jurnal Psikologi Pendidikan Dan Konseling, 3(1), 53-60.

Metasari, A. (2019). Pengaruh Kecerdasan Emosional dan Kecerdasan Spiritual Terhadap Prestasi Belajar Akidah Akhlak Siswa Kelas IX MTS Makrifatul Ilmi Kabupaten Bengkulu Selatan. IAIN Bengkulu.

Muhammad, P., Bin, A., Kadir, A., \& Hasyim, P. S. (2017). Proceedings International Conference On Indonesian Islam, Education And Science (ICIIES) 2017.

Nur Hanifah, U. (2018). Pembinaan Kecerdasan Emosional dan Spiritual (Studi Kasus Pada Siswa Kelas XI TPB SMK Saraswati Salatiga Tahun 2017). Institut Agama Islam Salatiga.

Putri, A. F. (2019). Konsep Perilaku Agresif Siswa. SCHOULID: Indonesian Journal of School Counseling, $4(1), 28-32$.

Rampisela, D. I., Rompas, S., \& Malara, R. (2017). Hubungan Kecerdasan Emosional dan Kecerdasan Spiritual Dengan Prestasi Belajar Siswa Di SMP Katolikst. Fransiskus Pineleng. E-Journal Keperawatan, 5(1), 2017.

Rasimin, Yusra, A., \& Wahyuni, H. (2021). Penerapan Bimbingan Belajar Berbasis Prinsip - Prinsip Belajar dalam Islam Untuk Meningkatkan Etika Belajar Siswa. EDUKATIF: Jurnal Ilmu Pendidikan, 3(2), 321-332.

Restu, Y., \& Yusri. (2013). Studi Tentang Perilaku Agresif Siswa di Sekolah. Jurnal Ilmiah Konseling, 2(1), 243-249.

Selviyana. (2020). Pelaksanaan Konseling Individual Dalam Pembentukan Kecerdasan Spiritual Siswa di MA Sumber Bungur Pakong Pemekasan. Institut Agama Islam Negeri Madura.

Sugiono. (2010). Metode Penelitian Pendidikan; Pendekatan Kuantitatif, Kualitatif dan R\&D (cetakan ke). Alfabeta, CV.

Sulastyaningrum, R., Martono, T., \& Wahyono, B. (2019). Pengaruh Kecerdasan Intelektual, Kecerdasan Emosional, dan Kecerdasan Spiritual terhadap Prestasi Belajar Mata Pelajaran Ekonomi pada Peserta Didik Kelas XI IPS di SMA Negeri 1 Bulu Tahun Ajaran 2017/2018. BISE: Jurnal Pendidikan Bisnis Dan Ekonomi, 4(2), 1-19.

Sumitri, F. (2017). Pengelolaan Program Bimbingan dan Konseling di Sekolah Menengah Atas. Jurnal Managemen Pendidikan, 11(6), 504-510.

Supriyadi. (2016). Community Of Practitioners: Solusi Alternatif Berbagi Pengetahuan Antar Pustakawan. Lentera Pustaka, 2(2), 83-93.

Tutiani. (2017). Kecerdasan Emosi dan Konforminas Dengan Perilaku Agresif Siswa SMK PAB 2 Helvetia Kabupaten Deli Serdang. Universitas Medan Area.

Ulandari, Y., \& Juliawati, D. (2019). Pemanfaatan Layanan Bimbingan Kelompok Untuk Meningkatkan Kecerdasan Emosi Siswa. Indonesian Journal of Counseling \& Development, 01(01), 1-8. 
588 Program Bimbingan Dan Konseling Untuk Mengembangkan Kecerdasan Spiritual Dan Emosional Siswa - Nanik Suryati, Mohammad Salehudin

DOI: https://doi.org/10.31004/edukatif.v3i2.349

Unnisa, S. S. (2019). Pengaruh Kecerdasan Emosional dan Kecerdasan Spiritual terhadap Hasil Belajar Akidah Akhlak Studi di MAN 2 Tanggerang Kelas X. Universitas Islam Negeri Sultan Maulana Hasanuddin.

Zed, M. (2014). Metode Penelitian Kepustakaan. Yayasan Pustaka Obor Indonesia. https://books.google.co.id/books?id=zG9sDAAAQBAJ 